PUBLIPRENEUR POLIMEDIA: JURNAL ILMIAH
JURUSAN PENERBITAN POLITEKNIK NEGERI MEDIA KREATIF

Vol. 7, No. 1, July 2019

Submitted: 5 July 2019

Revised: 15 July 2019

Accepted: 30 July 2019

\title{
TRAINING SHORT STORY WRITING FOR MASS MEDIA IN THE MIDDLE SCHOOL OF BUDI AGUNG
}

\author{
Faudunasokhi Telaumbanua, ${ }^{1}$ Salam Irianto Nadeak ${ }^{2}$ \\ Politeknik Negeri Media Kreatif \\ Program Studi Diluar Kampus Utama (PSDKU) Medan \\ E-mail: faudunasokhitelaumbanua@yahoo.com
}

\begin{abstract}
Literacy cannot be separated from the world of education. Literacy refers to the ability to solve problems and achieve life goals by using text as the primary medium, orally, and in writing. Literacy activities are part of the character education process through reading and writing skills. This means that character education can be obtained through reading and writing, for example, short stories. By reading and writing short stories, it is hoped that Indonesian students will be nurtured to become religious, integrity, nationalist, independent, and have cooperation. Besides, short stories that have been written can be sent to the mass media and become one of the coffers of income for students. On this basis, this community service proposal is aimed at developing a culture of literacy among students as well as building an entrepreneurial spirit by sending short stories to mass media.
\end{abstract}

Keywords: short stories, mass media, training, students.

\section{INVESTIGAS LEVEL KEBISINGAN (L-MIN dan L-MAX) DI LAB PERCETAKAN POLITEKNIK NEGERI MEDIA KREATIF, JAKARTA}

Literasi tidak dapat dipisahkan dari dunia pendidikan. Literasi pada hakikatnya mengacu pada kemampuan mengatasi masalah dan mencapai tujuan hidup dengan menggunakan teks sebagai media utamanya, secara lisan dan tulis. Aktivitas berliterasi merupakan salah satu bagian dari proses pendidikan karakter melalui kemampuan membaca dan menulis. Hal itu berarti bahwa pendidikan karakter dapat diperoleh melalui membaca dan menulis, misalnya cerita pendek. Dengan membaca dan menulis cerita pendek diharapkan para siswa Indonesia terbina menjadi pribadi yang religius, berintegritas, nasionalis, mandiri, dan memiliki sifat gotong royong. Selain itu, cerita pendek yang telah ditulis dapat dikirimkan ke media massa dan menjadi salah satu pundi-pundi penghasilan bagi siswa.. Atas dasar itu, proposal pengabdian masyarakat ini ditujukan untuk mengembangkan budaya literasi di kalangan siswa sekaligus membangun jiwa wirausaha melalui pengiriman cerita pendek ke media massa.

Kata kunci: Cerpen, Media Massa, Pelatihan, Siswa.

\section{PENDAHULUAN}

Indonesia berada dalam era perkembangan informasi yang identik dengan era literasi. Dictionary of Problem Words and Expressions (dalam analisis Irianto, 2007) menyatakan bahwa literasi berkenaan dengan huruf. Literasi, oleh
UNESCO didefinisikan sebagai kemampuan mengidentifikasi, memahami, menginterpretasi, mencipta, mengkomunikasikan, dan menghitung dengan menggunakan bahan cetak dan tertulis dalam konteks yang beragam. 
Salah satu bagian dari aktivitas literasi yang menjalar ke berbagai lini adalah cerita pendek. Pengertian pendek sungguh tidak begitu jelas ukurannya, kendati demikian menurut Sumardjo dan Saini dalam uraian Pujiono (2006), cerita pendek adalah cerita yang berbentuk proses yang relatif pendek. Sebagai bagian dari karya sastra, cerita pendek merupakan produk peradaban dan refleksi kehidupan suatu masyarakat atau bangsa. Di dalam cerita pendek tercermin nilar nilai budaya yang perlu digali, dikembangkan, dan dimasyarakatkan sebagai upaya untuk memantapkan karakter bangsa. Literasi pada hakikatnya mengacu pada kemampuan mengatasi masalah dan mencapai tujuan hidup dengan menggunakan teks sebagai media utamanya, secara lisan dan tulis.

Aktivitas berliterasi merupakan salah satu bagian dari proses pendidikan karakter melalui kemampuan membaca dan menulis. Hal itu berarti bahwa pendidikan karakter dapat diperoleh melalui membaca dan menulis cerita pendek. Dengan membaca dan menulis cerita pendek diharapkan para pemuda Indonesia terbina menjadi pribadi yang religius, berintegritas, nasionalis, mandiri, dan memiliki sifat gotong royong. Selain itu, cerita pendek yang telah ditulis dapat dikirimkan ke media massa dan menjadi salah satu pundi-pundi penghasilan bagi pemuda. Kemampuan merespon peristiwa, keadaan sosial, fenomena alam, dan sebagainya dalam bentuk karya sastra merupakan sebuah aktivitas literasi yang bernilai.

Minimnya gairah berliterasi siswa SMA Budi Agung merupakan bagian dari pekerjaan rumah para insan cendekia Indonesia. Atas dasar pandangan tersebut, pelatihan cerpen untuk media massa ini ditawarkan sebagai salah satu solusi guna meningkatkan kualitas budaya literasi pada siswa Budi Agung. Dalam pelatihan ini, para siswa dibimbing untuk meningkatkan kualitas membaca dan menulis, serta kemampuan membaca pasar kepenulisan di Indonesia.

Sasaran dalam penelitian ini adalah siswa SMA Budi Agung kelas X, XI, dan XII. Untuk tiap tingkatan kelas tersebut, para siswa akan dibekali kemampuan menulis yang dapat dipergunakan untuk menunjang kreativitas dan mengembangkan jiwa kewirausahaan. Dengan demikian kompetensi yang dimiliki para siswa berkembang secara maksimal dan berdaya guna.

\section{METODE PENELITIAN}

Pelatihan menulis cerpen untuk media massa akan dilaksanakan selama enam bulan. Untuk kelancaran pelaksanaan kegiatan yang telah direncanakan, pendekatan dilakukan melalui proses audiensi dan diskusi intensif bersama segenap civitas akademik sekolah serta para siswa. Selanjutnya, dalam setiap pertemuan, peserta akan dibimbing oleh pemateri yang memiliki kecakapan menulis cerpen. Mulai dari pemberian materi awal seputar penulisan cerpen untuk media massa, proses penulisan, hingga proses editing. Selain itu, siswa akan dibimbing untuk mengirimkan tulisannya ke media massa.

\section{HASIL DAN PEMBAHASAN}

Pelaksanaan Pelatihan Menulis Cerpen di SMA Budi Agung diawali dengan sejumlah persiapan yang berkaitan dengan aktivitas di sekolah yang bersangkutan. Mulai dari kunjungan untuk menyosialisasikan program, penyepakatan, pembidikan peserta, hingga persiapan untuk pelaksanaan program. seperti yang telah dipaparkan pada bagian sebelumnya, kegiatan ini dari pelatihan menulis cerita pendek ini dibagi atas tiga proses. Pertama, pemaparan definisi-definisi dasar mengenai cerita pendek dan bagaimana cara menulisnya. Kedua, proses menulis cerita pendek melalui berbagai strategi 
penulisan. Ketiga, proses diskusi dan evaluasi cerita pendek yang telah dihasilkan oleh para siswa serta bimbingan teknis pengiriman cerita pendek di media massa. Terutama mengenai hal-hal yang bersangkutan dengan etika kepenulisan dan etika jurnalistik. Prosedur kerja ini tentu melibatkan segenap tim pelaksana, pihak sekolah, maupun pihak-pihak lain yang memiliki relasi dengan pelatihan ini.

Strategi tersebut tepat sasaran. Di SMA Budi Agung sudah ada kegiatan ekstrakulikuler "Sastra" yang diasuh oleh salah seorang guru Bahasa Indonesia di sekolah itu. Namun, ternyata dalam kegiatan ekstrakulikuler tersebut pelatihan menulis cerita pendek sangat jarang diadakan. Siswa lebih sering dilatih untuk ber-drama, sedangkan aktivitas yang berhubungan dengan tulisan sangat minim.

Kondisi itu diungkapkan oleh para siswa yang menjadi peserta pelatihan menulis ini. Sebagian dari para siswa tersebut memiliki minat dan bakat menulis. Sayangnya tidak mendapat bimbingan dengan baik. Atas dasar tersebut, maka pelatihan menulis cerpen untuk media massa semakin menarik perhatian para siswa bahkan pihak sekolah. Berikut paparan satu per satu pelatihan yang dilakukan di SMA Budi Agung.

Selain membuka kegiatan, pada sesi ini dilakukan pemaparan seluk beluk gerakan literasi, hakikat cerita pendek, membaca cerita pendek penulis Sumatra Utara, dan proses menulis cerita pendek (menentukan ide, gagasan, alur, sudut pandang, tokoh, penokohan, dan latar.

Pengetahuan siswa mengenai cerita pendek para pengarang di Sumatra Utara sangat minim. Sejumlah nama penulis yang sebagian besar diketahui oleh mereka adalah penulis-penulis buku yang karyanya sudah difilmkan dan tokohnya menjadi viral. Simpulan tersebut diperoleh berdasarkan beberapa kali 'pancingan' yang dilontarkan oleh pemateri melalui pertanyaan singkat tentang penulis cerita pendek yang ada di Indonesia. Setelah mengetahui wawasan para siswa tersebut, aktivitas dilanjutkan dengan memberikan motivasi-motivasi menulis kepada para siswa. Selain memberi gambaran ihwal prospek dari profesi penulis, pada sesi ini siswa juga diajak untuk berdialog tentang hambatan-hambatan yang dialami dalam proses menulis.

Dua puluh siswa yang menjadi peserta pelatihan tampak sangat antusias mendengarkan arahan dan motivasi yang diberikan oleh pemateri. Sejumlah pertanyaan yang muncul misalnya, "Bagaimana mengatasi turun naikknya mood dalam menulis?", "Bagaimana cara agar bisa menjadi penulis?" serta pertanyaan-pertanyaan lain yang berhubungan dengan dunia literasi. Antusiasme para siswa menjadi pembuka yang sangat positif untuk kegiatan ini.

Aktivitas menulis yang seringkali dinilai membosankan menjadi satu permasalahan yang diluluhkan. Atas dasar itu, kegiatan menulis cerita pendek diawali dengan games bercerita.

Dalam menulis cerita pendek, kemampuan dasar yang harus dimiliki oleh oara siswa adalah kemampuan bercerita dengan menarik. Sayangnya, masih banyak siswa yang bingung bagaimana cara bercerita itu. Maka, games bercerita ini bertujuan untuk melatih kemampuan siswa bercerita.

Melaluigames bercerita siswa dilatih untuk menceritakan peristiwa yang paling berkesan yang pernah dialaminya kepada rekan yang ada di hadapannya. Siswa bercerita secara bergantian. Setalah saling bercerita, siswa diminta untuk mengidentifikasi unsur-unsur intrinsik cerita rekannya. Bergerak dari cerita-cerita tersebut, kemudian siswa dibimbing untuk memahami lebih dalam tentang unsurunsur cerita mereka. Termasuk, teknik bercerita yang menarik.

Pada dasarnya para siswa memiliki kemampuan untuk bercerita, tapi kendala 
ketika menulis adalah siswa kebingungan untuk merangkai dan mengolah ide cerita mereka menjadi cerita pendek yang baik. Maka, cerita pendek yang dihasilkan oleh para siswa cenderung monoton, tidak memenuhi unsur intrinsik dan ekstrinsik yang baik, serta tidak memiliki alur cerita yang menarik dibaca.

Tidak hanya itu, berhubung pelatihan menulis cerita pendek ini diadakan pada siang hari usai kegiatan belajar mengajar sekolah, games bercerita ini sekaligus berfungsi untuk membakar kembali semangat para siswa. Salah satunya juga untuk menghilangkan kantuk dan lelah.

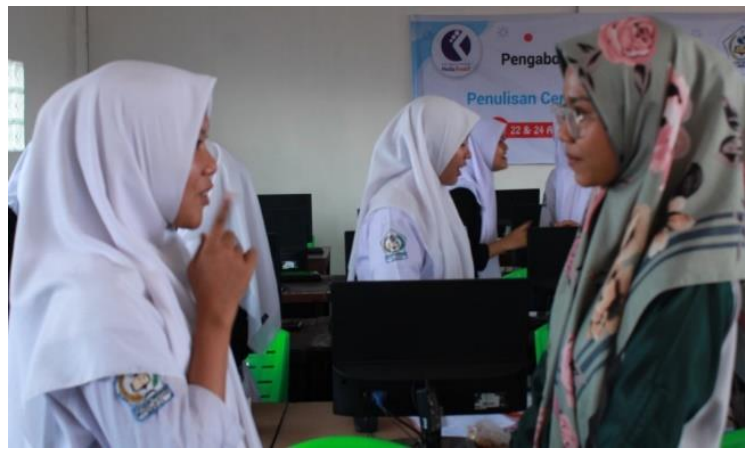

Setelah games bercerita, barulah materi mengenai cerita pendek secara intesntif disampaikan kepada seluruh siswa. Materi dikemas dengan semenarik mungkin dan lebih sederhana agar mudah dipahami oleh para peserta. Berikut materi tentang teknik menulis cerita pendek yang telah diberikan kepada seluruh peserta.

Setelah materi ini, siswa ditugaskan untuk menulis sebuah cerita pendek yang bertema kehidupan sehari-hari, seperti keluarga, sosial, dan cinta. Adapun persyaratan yang ditentukan disesuaikan dengan persyaratan pengiriman naskah cerita pendek ke media massa, yaitu: ditulis di kertas A4 dengan jumlah 3-5 halaman, spasi 1,5, dan menggunakan huruf Times New Roman 12 pt.

Pada pertemuan selanjutnya, cerita pendek yang ditulis oleh siswa dikumpulkan kepada pembimbing untuk dipantau kualitasnya. Berikut tiga contoh tulisan siswa yang mengikuti pelatihan.

Tulisan para siswa yang mengikuti pelatihan mayoritas masih memiliki kesalahan dalam penggunaan tanda baca, penulisan preposisi, penggunaan huruf kapital, dan penulisan ejaan. Kesalahankesalahan tersebut diperburuk dengan minimnya pengetahuan mengenai teknik menulis dialog dalam sebuah cerita pendek.

$$
\text { Masalah-masalah tersebut }
$$

merupakan persoalan krusial yang harus segera dibenahi. Atas dasar itulah maka diadakan kelas penyuntingan teks cerita pendek masing-masing peserta agar layak untuk dikirimkan ke media massa.

Usai aktivitas penyuntingan, kegiatan puncak dalam pelatihan ini pembimbingan pengiriman tulisan ke media massa. Pengiriman tulisan dilakukan melalui surat elektronik (email) masingmasing siswa. Pada tahap ini, secara serentak, siswa dipandu untuk mengirimkan tulisannya ke beberapa media, yaitu Analisa, Waspada, dan Medan Pos. Proses pengiriman karya siswa ke media massa berlangsung lancar berkat dukungan fasilitas dari pihak sekolah.

Sekitar tiga minggu dari kegiatan pelatihan, salah satu karya siswa peserta pelatihan terbit di surat kabar Medan Pos.

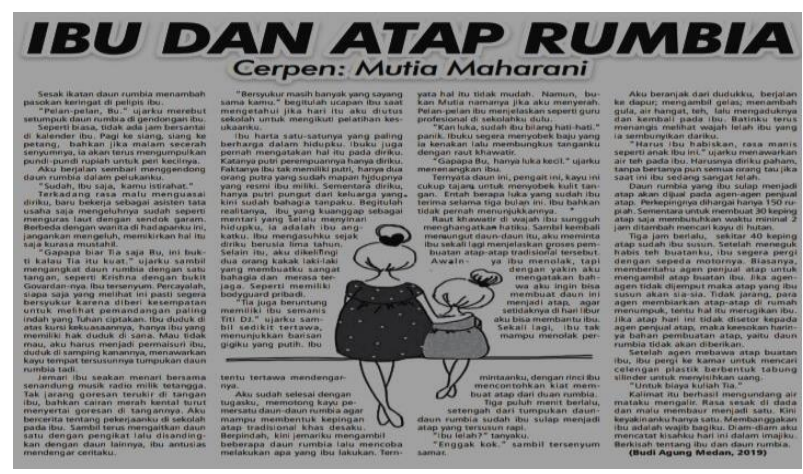

\section{SIMPULAN}

Pelatihan menulis cerita pendek untuk media massa telah selesai diaksanakan. Kegiatan ini diharapkan dapat bermanfaat bagi para peserta untuk memaksimalkan potensi menulis cerita 
pendek yang dimiliki. Selain itu, dengan pengetahuan teknik pengiriman cerita pendek ke media massa, diharapkan dapat menjadi salah satu alternatif untuk memupuk jiwa wirausaha bagi siswa. Salah satunya dengan 'menjual' tulisan. Di samping itu, tentu saja kegiatan ini sangat bermanfaat untuk mengembangkan potensi ssiwa dalam menulis cerita pendek.

Selanjutnya, keberhasilan

penyelenggaraan kegiatan "Pelatihan

Penulisan Cerpen untuk Media Massa" ditentukan oleh semua unsur yang berkepentingan dalam melaksanakan kegiatan secara tertib, teratur, penuh disiplin dan rasa tanggung jawab yang tinggi. Yakni dengan memahami pedoman ini diharapkan panitia penyelenggara, peserta, dan pihak-pihak lain dapat melaksanakan tugas dengan sebaik-baiknya sehingga kegiatan ini dapat mencapai hasil secara optimal. Maka, kami pun mengucapkan terima kasih kepada seluruh pihak yang telah membantu terselenggaranya kegiatan ini, terutama pada SMA Budi Agung Medan.

\section{DAFTAR PUSTAKA}

Admodiwiro, S. (2005). Manajemen Pelatihan. Jakarta: Ardadizya Jaya

Fatimah, K. (2008). Pentingnya Pendidikan dan Pelatihan Era Globalisasi. Malang: Erlangga.

Heinich, dkk. (1982). Instructional Media. Canada: John Wiley and Sons. Inc

Sadiman. A.S., dkk. (2006). Media Pendidikan. Jakarta: Rajawali Pers.

Siregar, E., Nara, H. (2010). Teori Belajar dan Pembelajaran. Bogor: Ghalia Indonesia.

Sudjana, D., (2007). Sistem dan Manajemen Pelatihan, Teori dan Aplikasi. Bandung: Falah Production.

Sujdana, N dan Ibrahim. (2007). Penelitian dan Penilaian Pendidikan. Bandung: Sinar Baru Algesindo.
Widoyoko, P, E. (2009). “Evaluasi Program Pelatihan". Jurnal -, -, 1-17. Wulandari, R. (2005). "Penilaian Kebutuhan Pelatihan: Tantangan Dan Solusi". Jurnal. 5, (1), 75-86.

Irianto, Putri Oviolanda, Lifia Yola febrianti. 2007. Pentingnya Penguasaan Literasi bagi Generasi Muda dalam Menghadapi MEA. Prosiding. The 1st Education and Language International Conference Proceedings Center for International Language Development of Unissula.

Pujiono, Muhammad. 2006. Analisis Nilai-Nilai Religius dalam Cerita Pendek

(Cerpen) karya Miyazawa Kenji. Universitas Sumatera Utara. 